\title{
Melatonine Can Promote the Growth of Malachium Aquaticum Seedlings under Salt Stress
}

\author{
Caifang Wu ${ }^{1, \mathrm{a}}$, Li Wang ${ }^{2, \mathrm{~b}}$, Yanling Huang ${ }^{1, \mathrm{c}}$, Qian Zhang ${ }^{1, \mathrm{~d}}$, and Lijin Lin ${ }^{3, \mathrm{e}^{\star}}$ \\ ${ }^{1}$ College of Horticulture, Sichuan Agricultural University, Chengdu, China \\ ${ }^{2}$ College of Animal Science and Technology, Sichuan Agricultural University, Chengdu, China \\ ${ }^{3}$ Institute of Pomology and Olericulture, Sichuan Agricultural University, Chengdu, China \\ a1843027126@qq.com, b510830161@qq.com, '15756256003@qq.com, d1964292607@qq.com, \\ ellj800924@163.com (Corresponding author)
}

Caifang Wu and Li Wang contributed equally to this work.

Keywords: Melatonine; Growth; Malachium aquaticum seedlings; Salt stress

Abstract: The effects of melatonine (MT) on the growth of Malachium aquaticum seedlings under salt stress were investigated through a pot experiment. The results showed that MT increased the biomass of $M$. aquaticum seedlings. With the increase of MT concentrations, the root, stem, leaf and shoot biomasses of $M$. aquaticum seedlings increased when the dose of MT was not more than 150 $\mu \mathrm{mol} / \mathrm{L}$, and decreased when the dose of MT was more than $150 \mu \mathrm{mol} / \mathrm{L}$. MT also enhanced the photosynthetic pigment content and antioxidant enzyme activity of $M$. aquaticum seedlings. When applying MT on M. aquaticum seedlings, the soluble sugar content in roots decreased, and the soluble sugar content in stems and leaves increased. Therefore, MT could promote the growth of $M$. aquaticum seedlings under salt stress, and the best dose of MT was $150 \mu \mathrm{mol} / \mathrm{L}$.

\section{Introduction}

Melatonin (MT) is a well-known animal hormones involved in the physiological regulation of vertebrates, including circadian rhythm and photoperiod response, and commonly used in adjusting improve sleep and treating neurasthenia [1] . In the animal field, MT is one of the hormones that can directly remove a variety of different forms of free radicals, and improve immunity [2]. MT not only presents in animals, but also presents in plants, which can be used as an effective free radical scavengers or antioxidants in plants under the abiotic stress [3]. MT also can regulate the growth and development of plants, such as promoting lateral root growth, changing florescence and delaying leaf senescence [4]. When applying MT on plant seedlings, the chlorophyll content significantly increases, and the photosynthetic ability significantly improves [5].

Malachium aquaticum is the wild vegetable of Caryophyllaceae [6]. In this study, we grew $M$. aquaticum seedlings under salt stress, and used the different concentrations of MT to treat $M$. aquaticum seedlings, to study the effects of MT on the growth of M. aquaticum seedlings under salt stress. The aim of the study was to screen the best MT concentration which could promote the growth of $M$. aquaticum seedlings under salt stress, and provided a reference for applying the plant hormones on other wild vegetables production under salt stress.

\section{Materials and Methods}

Materials. The $M$. aquaticum seedlings with height of $15 \mathrm{~cm}$ were collected from the surrounding farmland of Chengdu campus of Sichuan Agricultural University $\left(30^{\circ} 42^{\prime} \mathrm{N}, 103^{\circ} 51^{\prime} \mathrm{E}\right)$ in March 2016.

Experimental Design. The vermiculites and pearlites $(1: 1)$ were put into polyethylene pot $(10 \mathrm{~cm}$ high, $10 \mathrm{~cm}$ in diameter). The base of $M$. aquaticum seedlings were immersed in 5 concentrations $(0$, 50, 100, 150 and $200 \mu \mathrm{mol} / \mathrm{L}$ ) of MT [7] solutions for $24 \mathrm{~h}$ in March 2016, respectively. Two uniform M. aquaticum seedlings were transplanted into each pot with 6 replicates for each treatment. After that, all of the seedlings were covered with transparent plastic film and a shade net. After $10 \mathrm{~d}$, the 
transparent plastic film and the shade net were removed. From the third day of transplanting, the Hogland nutrient solutions containing $50 \mathrm{mmol} / \mathrm{L} \mathrm{NaCl}$ [8] were watered every two days, and $30 \mathrm{ml}$ solutions for each pot. When M. aquaticum seedlings grow two month (May 2016) under salt stress, the upper mature leaves of $M$. aquaticum seedlings were collected to determine the photosynthetic pigment (chlorophyll $a$, chlorophyll $b$ and total chlorophyll) contents [9]. The upper young shoots (2 $\mathrm{cm}$ in length) were collected to determine the superoxide dismutase (SOD) activity, peroxidase (POD) activity and catalase (CAT) activity [10]. Then, the whole plants were then gently removed. The roots and shoots were washed with tap water followed by deionized water, and the biomasses of root, stem and leaf were measured. After that, the roots, stems and leaves of M. aquaticum seedlings were dried at $80{ }^{\circ} \mathrm{C}$ to constant weight. The dried tissue samples were finely ground and sieved through a $0.149-\mathrm{mm}-\mathrm{mesh}$ nylon sieve for chemical analysis. The soluble sugar contents in roots, stems and leaves of $M$. aquaticum seedlings were determined by anthrone colorimetry with dry weight plant samples [11].

Statistical Analyses. Statistical analyses were conducted using SPSS 13.0 statistical software (IBM, Chicago, IL, USA). Data were analyzed by one-way analysis of variance with Duncan's multiple range test $(\mathrm{p}=0.05$ confidence level).

\section{Results and Discussion}

Biomass of M. aquaticum Seedlings. After the treatments of different concentrations of MT, the root biomass of $M$. aquaticum seedlings increased compared with the control under salt stress (Table 1). With the increase of MT concentrations, the root biomass of $M$. aquaticum seedlings increased when the dose of MT was not more than $150 \mu \mathrm{mol} / \mathrm{L}$, and decreased when the dose of MT was more than $150 \mu \mathrm{mol} / \mathrm{L}$. At 50, 100, 150 and $200 \mu \mathrm{mol} / \mathrm{L} \mathrm{MT}$, the root biomass increased by $5.51 \%(p>0.05)$, $16.91 \%(p<0.05), 22.91 \%(p<0.05)$ and 5.70\% $(p>0.05)$ respectively, compared with the control. When applying MT on $M$. aquaticum seedlings under salt stress, the stem, leaf and shoot biomasses of M. aquaticum seedlings increased compared with the control (Table 1). With the increase of MT concentrations, the trends of stem, leaf and shoot biomasses were the same as the root biomass. At 50, 100,150 and $200 \mu \mathrm{mol} / \mathrm{L} \mathrm{MT}$, the shoot biomass increased by $15.04 \%(p>0.05), 30.89 \%(p>0.05)$, $52.75 \%(p<0.05)$ and $2.04 \%(p>0.05)$ respectively, compared with the control. So, MT could promote the growth of $M$. aquaticum seedlings, and the $150 \mu \mathrm{mol} / \mathrm{L}$ MT was the best concentration.

Table 1 The biomass of $M$. aquaticum seedlings

\begin{tabular}{|c|c|c|c|c|}
\hline $\begin{array}{c}\text { MT concentration } \\
(\mu \mathrm{mol} / \mathrm{L})\end{array}$ & $\begin{array}{c}\text { Roots } \\
(\mathrm{g} / \text { plant FW })\end{array}$ & $\begin{array}{c}\text { Stems } \\
(\mathrm{g} / \text { plant FW })\end{array}$ & $\begin{array}{c}\text { leaves } \\
(\mathrm{g} / \text { plant FW })\end{array}$ & $\begin{array}{c}\text { Shoots } \\
(\mathrm{g} / \text { plant FW })\end{array}$ \\
\hline 0 & $1.017 \pm 0.028 \mathrm{~b}$ & $6.419 \pm 1.378 \mathrm{a}$ & $4.193 \pm 0.873 \mathrm{~b}$ & $10.612 \pm 2.260 \mathrm{~b}$ \\
\hline 50 & $1.073 \pm 0.054 \mathrm{~b}$ & $6.876 \pm 1.307 \mathrm{a}$ & $5.332 \pm 0.865 \mathrm{ab}$ & $\begin{array}{l}12.208 \pm 0.441 \mathrm{a} \\
\mathrm{b}\end{array}$ \\
\hline 100 & $1.189 \pm 0.016 \mathrm{a}$ & $7.379 \pm 1.331 \mathrm{a}$ & $6.511 \pm 0.692 \mathrm{ab}$ & \multicolumn{2}{|c|}{$13.890 \pm 2.022 \mathrm{a}$} \\
\hline 150 & $1.250 \pm 0.010 \mathrm{a}$ & $8.895 \pm 0.417 \mathrm{a}$ & $7.315 \pm 1.563 \mathrm{a}$ & $16.210 \pm 1.980 \mathrm{a}$ \\
\hline 200 & $1.075 \pm 0.047 \mathrm{~b}$ & $6.551 \pm 1.766 \mathrm{a}$ & $4.278 \pm 1.021 \mathrm{~b}$ & \multicolumn{2}{|c|}{$10.829 \pm 2.787 \mathrm{a}$} \\
\hline
\end{tabular}

Values are means $( \pm \mathrm{SE})$ of six replicate pots. Different lowercase letters within a column indicate significant differences (one-way analysis of variance followed by Duncan's multiple range test; $p<$ $0.05)$.

Photosynthetic Pigment Content of $M$. aquaticum seedlings. The same as the biomass of $M$. aquaticum seedlings, MT increased the contents of chlorophyll $a$, chlorophyll $b$ and total chlorophyll under salt stress (Table 2). With the increase of MT concentrations, the contents of chlorophyll $a$, chlorophyll $b$ and total chlorophyll increased when the dose of MT was not more than $150 \mu \mathrm{mol} / \mathrm{L}$, and decreased when the dose of MT was more than $150 \mu \mathrm{mol} / \mathrm{L}$. At 50, 100, 150 and $200 \mu \mathrm{mol} / \mathrm{L} \mathrm{MT}$, the chlorophyll $a$ content increased by $24.12 \%(p<0.05), 59.22 \%(p<0.05), 67.06 \%(p<0.05)$ and 
$9.02 \%(p>0.05)$ respectively, the chlorophyll $b$ content increased by $15.95 \%(p<0.05), 60.78 \%(p<$ $0.05), 68.97 \%(p<0.05)$ and $10.34 \%(p<0.05)$ respectively, the total chlorophyll content increased by $22.51 \%(p<0.05), 59.46 \%(p<0.05), 67.28 \%(p<0.05)$ and $9.18 \%(p>0.05)$ respectively, compared with the respective control. For the chlorophyll a/b, $50 \mu \mathrm{mol} / \mathrm{L}$ MT increased the chlorophyll a/b of $M$. aquaticum seedlings, and the other contrations of MT decreased chlorophyll $\mathrm{a} / \mathrm{b}$ of $M$. aquaticum seedlings (Table 2).

Table 2 The photosynthetic pigment content of $M$. aquaticum seedlings

\begin{tabular}{|c|c|c|c|c|}
\hline $\begin{array}{c}\text { MT concentration } \\
(\mu \mathrm{mol} / \mathrm{L})\end{array}$ & $\begin{array}{c}\text { Chlorophyll } a \\
(\mathrm{mg} / \mathrm{g})\end{array}$ & $\begin{array}{c}\text { Chlorophyll } b \\
(\mathrm{mg} / \mathrm{g})\end{array}$ & $\begin{array}{c}\text { Total chlorophyll } \\
(\mathrm{mg} / \mathrm{g})\end{array}$ & $\begin{array}{c}\text { Chlorophyll } \\
\mathrm{a} / \mathrm{b}\end{array}$ \\
\hline 0 & $1.020 \pm 0.016 \mathrm{c}$ & $0.232 \pm 0.008 \mathrm{c}$ & $1.253 \pm 0.023 \mathrm{c}$ & 4.397 \\
\hline 50 & $1.266 \pm 0.018 \mathrm{~b}$ & $0.269 \pm 0.002 \mathrm{~b}$ & $1.535 \pm 0.020 \mathrm{~b}$ & 4.706 \\
\hline 100 & $1.624 \pm 0.051 \mathrm{a}$ & $0.373 \pm 0.004 \mathrm{a}$ & $1.998 \pm 0.056 \mathrm{a}$ & 4.354 \\
\hline 150 & $1.704 \pm 0.059 \mathrm{a}$ & $0.392 \pm 0.005 \mathrm{a}$ & $2.096 \pm 0.064 \mathrm{a}$ & 4.347 \\
\hline 200 & $1.112 \pm 0.009 \mathrm{c}$ & $0.256 \pm 0.008 \mathrm{~b}$ & $1.368 \pm 0.017 \mathrm{c}$ & 4.344 \\
\hline
\end{tabular}

Values are means $( \pm$ SE) of six replicate pots. Different lowercase letters within a column indicate significant differences (one-way analysis of variance followed by Duncan's multiple range test; $p<$ $0.05)$.

Antioxidant Enzyme Activity of M. aquaticum seedlings. After the treatment of MT under salt stress, the antioxidant enzyme activity of $M$. aquaticum seedlings enhanced (Table 3 ). So, MT could improve the resistance of $M$. aquaticum seedlings to salt stress. At 50, 100, 150 and $200 \mu \mathrm{mol} / \mathrm{L} \mathrm{MT}$, the SOD activity increased by $83.06 \%(p<0.05), 126.61 \%(p<0.05), 206.53 \%(p<0.05)$ and $42.52 \%(p<0.05)$ respectively, the POD activity increased by $10.03 \%(p>0.05), 19.16 \%(p<0.05)$, $30.46 \%(p<0.05)$ and $1.90 \%(p>0.05)$ respectively, the CAT activity increased by $7.85 \%(p>0.05)$, $16.15 \%(p<0.05), 22.82 \%(p<0.05)$ and $7.77 \%(p>0.05)$ respectively, compared with the respective control.

Table 3 The antioxidant enzyme activity of M. aquaticum seedlings

\begin{tabular}{|c|c|c|c|}
\hline $\begin{array}{c}\text { MT concentration } \\
(\mu \mathrm{mol} / \mathrm{L})\end{array}$ & $\begin{array}{c}\text { SOD activity } \\
(\mathrm{U} / \mathrm{g})\end{array}$ & $\begin{array}{c}\text { POD activity } \\
(\mathrm{U} / \mathrm{g})\end{array}$ & $\begin{array}{c}\text { CAT activity } \\
(\mathrm{U} / \mathrm{g})\end{array}$ \\
\hline 0 & $31.23 \pm 1.80 \mathrm{e}$ & $1210.74 \pm 26.88 \mathrm{~d}$ & $79.76 \pm 4.55 \mathrm{c}$ \\
\hline 50 & $57.17 \pm 4.52 \mathrm{c}$ & $1332.14 \pm 51.52 \mathrm{bc}$ & $86.02 \pm 4.59 \mathrm{bc}$ \\
\hline 100 & $70.77 \pm 0.22 \mathrm{~b}$ & $1442.68 \pm 58.55 \mathrm{~b}$ & $92.64 \pm 3.81 \mathrm{ab}$ \\
\hline 150 & $95.73 \pm 3.80 \mathrm{a}$ & $1579.59 \pm 14.84 \mathrm{a}$ & $97.96 \pm 2.62 \mathrm{a}$ \\
\hline 200 & $44.51 \pm 2.93 \mathrm{~d}$ & $1233.80 \pm 52.15 \mathrm{~cd}$ & $85.96 \pm 1.69 \mathrm{bc}$ \\
\hline
\end{tabular}

Values are means $( \pm \mathrm{SE})$ of six replicate pots. Different lowercase letters within a column indicate significant differences (one-way analysis of variance followed by Duncan's multiple range test; $p<$ $0.05)$.

Soluble Sugar Content in M. aquaticum seedlings. When applying MT on M. aquaticum seedlings, the soluble sugar content in roots of $M$. aquaticum seedlings decreased, and the soluble sugar content in stems and leaves increased under salt stress (Table 4). At 50, 100, 150 and $200 \mu \mathrm{mol} / \mathrm{L} \mathrm{MT}$, the soluble sugar content in roots decreased by $9.16 \%(p<0.05), 10.74 \%(p<0.05), 14.60 \%(p<0.05)$ and $19.46 \%(p<0.05)$ respectively, the soluble sugar content in stems increased by $6.70 \%(p<0.05)$, $22.32 \%(p<0.05), 47.05 \%(p<0.05)$ and $2.95 \%(p<0.05)$ respectively, the soluble sugar content in leaves increased by $14.37 \%(p<0.05), 14.93 \%(p<0.05), 33.56 \%(p<0.05)$ and $14.03 \%(p<0.05)$ respectively, compared with the respective control. So, MT could adjust the distribution ratio of soluble sugar in source, stream and sink of plants.

\section{Conclusions}

Under salt stress, MT increased the biomass of M. aquaticum seedlings. With the increase of MT concentrations, the root, stem, leaf and shoot biomasses of $M$. aquaticum seedlings increased when 
the dose of MT was not more than $150 \mu \mathrm{mol} / \mathrm{L}$, and decreased when the dose of MT was more than $150 \mu \mathrm{mol} / \mathrm{L}$. MT also enhanced the photosynthetic pigment content and antioxidant enzyme activity of $M$. aquaticum seedlings. When applying MT on M. aquaticum seedlings, the soluble sugar content in roots decreased, and the soluble sugar content in stems and leaves increased. Therefore, MT could promote the growth of $M$. aquaticum seedlings under salt stress.

Table 4 The soluble sugar content in M. aquaticum seedlings

\begin{tabular}{|c|c|c|c|}
\hline $\begin{array}{c}\text { MT concentration } \\
(\mu \mathrm{mol} / \mathrm{L})\end{array}$ & $\begin{array}{c}\text { Roots } \\
(\mathrm{mg} / \mathrm{g} \mathrm{DW})\end{array}$ & $\begin{array}{c}\text { Stems } \\
(\mathrm{mg} / \mathrm{g} \mathrm{DW})\end{array}$ & $\begin{array}{c}\text { leaves } \\
(\mathrm{mg} / \mathrm{g} \mathrm{DW})\end{array}$ \\
\hline 0 & $18.35 \pm 0.58 \mathrm{a}$ & $11.20 \pm 0.50 \mathrm{c}$ & $8.91 \pm 0.24 \mathrm{~b}$ \\
\hline 50 & $16.67 \pm 0.76 \mathrm{~b}$ & $11.95 \pm 1.04 \mathrm{c}$ & $10.19 \pm 0.07 \mathrm{~b}$ \\
\hline 100 & $16.38 \pm 0.87 \mathrm{bc}$ & $13.70 \pm 0.74 \mathrm{~b}$ & $10.24 \pm 0.78 \mathrm{~b}$ \\
\hline 150 & $15.67 \pm 0.27 \mathrm{bc}$ & $16.47 \pm 0.49 \mathrm{a}$ & $11.90 \pm 1.15 \mathrm{a}$ \\
\hline 200 & $14.78 \pm 0.48 \mathrm{c}$ & $11.53 \pm 0.17 \mathrm{c}$ & $10.16 \pm 0.21 \mathrm{~b}$ \\
\hline
\end{tabular}

Values are means $( \pm \mathrm{SE})$ of six replicate pots. Different lowercase letters within a column indicate significant differences (one-way analysis of variance followed by Duncan's multiple range test; $p<$ $0.05)$.

\section{Acknowledgements}

This work was financially supported by the Undergraduate Thesis Breeding Program of Sichuan Agricultural University (2015).

\section{References}

[1] R.J. Reiter: Endocrine Reviews Vol 12 (1991), p. 151.

[2] D.X. Tan, L.C. Manchester, R. Hardeland, S. Lopez-Burillo, J.C. Mayo, R.M. Sainz and R.J. Reiter: Journal of Pineal Research Vol 34 (2003), p. 75.

[3] Q.H. Gao, Y.K. Ya, X.M. Lu and Y.M. Miao: Acta Botanica Boreali-Occidentalia Sinica Vol 34 (2014), p. 1608.

[4] J. Ye, X.P. Deng, S.W. Wang, L.N. Yin, D.G. Chen, B.L. Xiong and X.Y. Wang: Journal of Triticeae Crops Vol. 35(2015), p. 1275.

[5] M.B. Arnao and J. Hernández-Ruiz: Journal of Pineal Research Vol 46 (2009), p. 58.

[6] X. Liu, X.P. Wu, W.D. Zhu, S.H. Wei and C.X. Zhang: Acta Phytophylacica Sinica Vol 33 (2006), p. 105.

[7] L.Y. Wang and K.F. Zhao: Acta Phytophylacica Sinica Vol 33 (2006), p. 105.

[8] N. Zhang, B. Zhao, H.J. Zhang, S. Weeda, C. Yang, Z.C. Yang, S. Ren and Y.D.Guo: Journal of Pineal Research Vol 54 (2013), p. 15.

[9] H.S. Li: Principle and Technology of Plant Physiology and Biochemistry Experiment (Higher Education Press, Beijing, China 2000).

[10]Q.E. Xiong: Plant Physiology Experiment Course (Sichuan Science and Technology Publishing House, Chengdu, China 2014).

[11]Z.B. Hao, J. Cang and Z. Xu: Plant Physiology Experiment (Harbin Institute of Technology Press, Harbin, China 2004). 